\title{
POCZUCIE TOŻSAMOŚCI MŁODZIEŻY DORASTAJĄCEJ. BADANIA JAKOŚCIOWE
}

MARCIN KŁOSOWSKI *

Papieski Wydział Teologiczny w Warszawie

\section{STRESZCZENIE}

Dorastanie to czas przejścia $\mathrm{z}$ okresu dzieciństwa do dorosłości. Jednym $z$ najistotniejszych zadań tego okresu jest ukształtowanie poczucia tożsamości. Zgodnie $\mathrm{z}$ teorią stadiów rozwoju psychospołecznego Erika Eriksona (1968), na okres adolescencji przypada kryzys tożsamościowy, a najważniejszym pytaniem staje się: kim jestem? W prezentowanym artykule szczegółowiej podjęto problem treści poczucia tożsamości oraz formy jego prezentacji u nastolatków w wieku 13-19 lat. Za pomocą autorskiego narzędzia przeprowadzono badania jakościowe wśród uczniów szkół gimnazjalnej oraz licealnej (badania zakończyły się jeszcze przed całkowitą likwidacją tego podziału szkół). W badaniu wzięło udział 188 uczniów ( $N=188$, uczniowie szkoły gimnazjalnej $n=96$, uczniowie szkoły licealnej $n=92$, średnia wieku $=16,20) . \mathrm{W}$ wyniku przeprowadzonych analiz okazało się, iz istnieją pewne różnice w zakresie treści i formy wypowiedzi na temat własnej tożsamości między uczniami szkół gimnazjalnej i licealnej. $\mathrm{Na}$ ich podstawie można również stwierdzić, że młodzież różnicują nie tylko konkretne treści, ale w ogóle umiejętność bądź nieumiejętność odpowiedzi na pytanie o to, kim się jest.
WPROWADZENIE

19 Okres dorastania

20 Kształtowanie poczucia tożsamości jako szczególne zadanie rozwojowe

21 Problem badań własnych

22 METODA

22 Osoby badane

22 Materiały/Zastosowane narzędzia

23 Procedura badania

23 Analiza jakościowa poczucia tożsamości

25 Częstości występowania poszczególnych kategorii

26 Zróżnicowanie uczniów gimnazjum i liceum w zakresie wypowiedzi na temat poczucia tożsamości

28 DYSKUSJA WYNIKÓW

30 BIBLIOGRAFIA 


\title{
THE SENSE OF IDENTITY AMONG ADOLESCENTS. THE QUALITATIVE RESEARCH
}

\begin{abstract}
Adolescence is a period of physical and mental transformation from childhood to adulthood. One of the most important tasks at that time is forming the sense of identity. According to Erikson (1968) an identity crisis occurs during that stage and the most important question appears "who am I?" The problem of the content and the form of the sense of identity among adolescents aged 13-19 has been discussed in the article. Qualitative research was conducted with the original tool among students of gymnasium and high school (the research was completed before the liquidation of gymnasium in Poland). 188 students participated in the study ( $N=188$, gymnasium students $n=96$, high school students $n=92$, mean age $=16.20$ ). As a result of the analyzes, it turned out that there are some differences in the content and form of statements between gymnasium and high school students. It can also be stated that adolescents differ not only in specific content, but also in the ability or disability to answer the question about the individual sense of identity.
\end{abstract}

\section{KEYWORDS}

sense of identity, adolescence, qualitative research 


\section{WPROWADZENIE}

\section{OKRES DORASTANIA}

sychologia rozwoju mocno podkreśla, iż zmiany w życiu człowieka zachodzą od momentu poczęcia aż do śmierci (Schaffer, Kipp, 2015). Każdy z etapów życia jednostki może mieć indywidualną dynamikę rozwoju, jednak istnieją także zmiany wspólne, charakterystyczne dla pewnych etapów życia. Dorastanie opisywane jest jako okres zaczynający się zwykle około 10.-12. roku życia, a kończący w wieku około 18-20 lat (Brzezińska, Appelt, Ziółkowska, 2010). Dolna granica tego okresu ma swoją konotację z rozwojem fizjologicznym i dojrzewaniem biologicznym. Górna granica związana jest bardziej z kontekstem społeczno-kulturowym. Niektóre z psychologicznych opracowań dzielą okres adolescencji na krótsze fazy, np. wczesne i późne dorastanie (Czerwińska-Jasiewicz, 2015; Filipiak, Wiśniewska, 2014).

Niewątpliwie okres dojrzewania to czas różnych i intensywnych przemian. Jaczewski (2001) podkreśla, że zmiany mają w tym okresie szczególne tempo, a akcent przesuwa się $z$ dominujących do tego momentu zmian ilościowych na rzecz jakościowych. W psychologii zwraca się uwagę na zmiany związane $\mathrm{z}$ rozwojem biologicznym, poznawczym, osobowości i moralnym. Są one w znacznej mierze powiązane ze sobą i mają pomóc w przejściu z okresu dzieciństwa do dorosłości.

Podstawowymi zmianami w okresie dojrzewania, będącymi fundamentem i motorem wielu następnych zmian, są zmiany w zakresie biologii. Powszechnie uznaje się, że znaczącą rolę w tym okresie odgrywa układ hormonalny (Jaczewski, 2001). Zmianom w sferze biologicznej współtowarzyszą zmiany w sferze psychicznej. W okresie dorastania następuje zmiana jakościowa $\mathrm{w}$ zakresie czynności poznawczych, w tym zdolności do myślenia hipotetyczno-dedukcyjnego. Młody człowiek uczy się dokonywać swobodnej refleksji oraz potrafi w sposób systematyczny rozwiązywać bardziej złożone problemy (Piaget, 1966, za: Brzezińska i in., 2010). W okresie dorastania następują także zarówno ilościowe, jak i jakościowe zmiany w rozwoju społecznym. Jak zauważa Ruszkowska (1997), rodzice nie moga już odgrywać tej samej roli co wcześniej i nadal zaspokajać potrzeb adolescenta. Kiedy rodzice zaczynają tracić swój wszechogarniający autorytet, na znaczeniu przybierają związki rówieśnicze i przyjacielskie, ważne są także pierwsze doświadczenia w relacjach intymnych. Adolescencja wiąże się dodatkowo $\mathrm{z}$ kształtowaniem autonomii moralnej, wyborem określonych wartości, różnicowaniem się światopoglądu. W tym czasie wyraźniej formują się postawy społeczne i polityczne. Nierzadko następują pierwsze kontakty z pracą zawodową (Obuchowska, 2000). Młodzi ludzie stają wobec różnych życiowych zadań, które mają aktywizować ich rozwój. Havighurst (1981) wymienia wśród nich m.in.: akceptowanie swojej fizyczności i zmian w obrębie ciała, osiągnięcie emocjonalnej niezależności od rodziców i innych dorosłych, uwewnętrznienie moralności, dokonywanie wyborów związanych $\mathrm{z}$ nauką, pracą i karierą zawodową, osiągnięcie niezależności ekonomicznej dzięki własnej aktywności, poszerzanie sprawności intelektualnych niezbędnych do rozwoju kompetencji obywatelskich, opanowanie społecznej roli związanej z płcią.

Finalnym rezultatem zmian zachodzących $\mathrm{w}$ okresie adolescencji powinno być osiągnięcie dojrzałości genitalnej oraz dojrzałości psychicznej. W ten sposób młody człowiek staje się gotowym do prokreacji w sensie biologicznym, a równocześnie do podejmowania różnorodnych zadań właściwych człowiekowi dorosłemu, w czym ma mu pomóc wypracowana dojrzała osobowość. 


\section{KSZTAŁTOWANIE POCZUCIA TOŻSAMOŚCI JAKO SZCZEGÓLNE ZADANIE ROZWOJOWE}

Tożsamość nie jest zdefiniowana ani skonceptualizowana $\mathrm{w}$ jeden, powszechnie obowiązujący sposób, a tej różnorodności definicji i koncepcji towarzyszy rozmaitość metod jej badania (Kubacka-Jasiecka, Kuleta, 2008). W psychologii najczęściej podejmuje się naukową refleksję nad poczuciem tożsamości rozumianym jako szczególny rodzaj całościowego i osobowego doświadczania siebie (Pilarska, 2016). Wśród psychologów panuje powszechne przekonanie, że ukształtowanie poczucia tożsamości jest jednym z najważniejszych zadań rozwojowych okresu adolescencji (Bardziejewska, 2013). Sam proces kształtowania się poczucia tożsamości ma przygotować młodego człowieka do okresu dorosłości, w którym będzie musiał zmierzyć się z licznymi wyzwaniami osobistymi, interpersonalnymi czy zawodowymi.

Młody człowiek, wkraczający w okres dojrzewania, wnosi ze sobą w ten etap zręby dotychczasowej tożsamości, która była mu potrzebna w poprzednich okresach rozwojowych jako baza poczucia swojej podmiotowości. Już wczesnodziecięce doświadczenia, mocno związane $\mathrm{z}$ identyfikowaniem się $\mathrm{z}$ dorosłymi, należy postrzegać jako przygotowanie do procesu tworzenia własnej tożsamości (Tillmann, 1996). Nie można więc powiedzieć, że poczucie tożsamości człowieka zaczyna się tworzyć dopiero w okresie dorastania. Jednak to właśnie wtedy, w wyniku wielu zmian fizycznych, psychicznych i społecznych, to dotychczasowe poczucie zostaje zachwiane, a tożsamość zakwestionowana. To dlatego Erikson (1968) nazywa ten stan kryzysem tożsamościowym, który jednocześnie jest psychicznym wyzwaniem okresu adolescencji. Najważniejszym pytaniem, na które musi znaleźć odpowiedź młody człowiek, jest pytanie: kim jestem?, a okres adolescencji to czas konfliktu nazwanego przez Eriksona (2012) tożsamość vs. pomieszanie ról. Kryzys tożsamości pojawiający się w okresie dorastania jest czymś naturalnym w życiu każdego człowieka. Stan ten związany jest z poczuciem zagubienia, wywołanym zarówno konfliktem psychicznym jednostki, jak i wymaganiami stawianymi przez społeczeństwo.

Marcia (1980), rozbudowując koncepcję Eriksona, zwrócił uwagę na dwa charakterystyczne procesy na drodze do formowania stabilnego poczucia tożsamości. Pierwszym z nich jest eksploracja, która jest czasem szukania przez młodego człowieka różnych alternatyw dla siebie, wchodzenia w różne role, czasami może objawiać się przez bunt. Drugim jest zaangażowanie, czyli podjęcie odpowiedzialności za ostatecznie dokonany wybór drogi, którą chce się podążać. $Z$ odpowiedniej konstelacji tych dwóch kryteriów wynika status tożsamości, jaki może charakteryzować człowieka kończącego okres dorastania i rozpoczynającego dorosłe życie.

Budowanie poczucia tożsamości jest wspólnym zadaniem rozwojowym dla ludzi w wieku dorastania, ale - tak jak każdy proces rozwojowy - może mieć indywidualny przebieg. Zarówno Erikson $(1968,2004)$, jak i Marcia (1980) zwracali uwagę na to, iż między poszukiwaniem i wypróbowywaniem nowych ról a ich rzeczywistym i ostatecznym wyborem (między eksplorowaniem a ostatecznym podjęciem zobowiązania) musi minąć trochę czasu i dla każdej osoby ten czas może być różny. Ten przejściowy okres jest w psychologii nazywany moratorium. Według Opoczyńskiej (1999) okres moratorium może być szansą dla młodego człowieka na odnalezienie swojej tożsamości, ale $\mathrm{z}$ drugiej strony jest czasem, który kryje w sobie wiele niebezpieczeństw. Badania wskazują, że współcześnie okres ten znacząco się wydłuża. Przyczyniają się do tego indywidualizm, subiektywizm oraz brak jednoznacznych kryteriów, których spełnienie pozwoliłoby młodym ludziom wyjść $z$ etapu eksperymentowania i poszukiwań (Lipska, Zagórska, 2011).

Młody człowiek w poszukiwaniu odpowiedzi na pytanie: kim jestem? musi jednocześnie znaleźć odpowiedzi na wiele innych pytań związanych $\mathrm{z}$ wieloma obszarami jego życia. Erikson (1997) wyróżniał siedem domen mających podstawowe znaczenie dla kształtowania się tożsamości: 1) rozwój perspektywy czasowej, 2) pewność siebie, 3) wypróbowywanie 
ról, 4) przewidywanie osiągnięć, 5) identyfikacja seksualna, 6) polaryzacja przywództwa, 7) polaryzacja ideologiczna. Kłym-Guba i Cieciuch (2016) w swoich podłużnych badaniach zaproponowali następujące domeny związane z poszukiwaniem tożsamościowym we wczesnej adolescencji: 1) wygląd fizyczny, 2) czas wolny, 3) rodzina pochodzenia, 4) praca, 5) relacje chłopak-dziewczyna, 6) formułowanie własnego zdania, 7) postrzeganie własnego miejsca w cyklu życia, 8) autorefleksja, 9) przyszłość, 10) przyszła rodzina, 11) światopogląd, 12) stosunek do zasad. Zaproponowane przez autorów 12 domen było wynikiem teoretycznych rozważań i analizy dostępnej literatury. Każda z wymienionych sfer wiąże się ze zdobywaniem nowych doświadczeń oraz umiejętnością integrowania ich zarówno z historią własnego życia, jak i z obecnymi wpływami społeczno-kulturowymi (Musiał, 2007). W fazie kryzysu tożsamościowego adolescent musi więc dokonywać samookreślenia w odniesieniu do wielu zagadnień związanych zarówno z życiem osobistym, jak i społecznym. Tak rozumiane poczucie tożsamości zbudowane jest więc $z$ wielu pomniejszych elementów, a odpowiedź na pytanie o własną tożsamość musi je w sobie zawierać.

Chociaż proces kształtowania się poczucia tożsamości rozpoczyna się w okresie adolescencji, to jednak nie musi wraz z końcem tego okresu definitywnie się kończyć. Badania wykazują, że rozwój poczucia tożsamości nie ma jednolitego charakteru (Marat, 2001; Rydz, 2005). Proces kształtowania tożsamości może też być z różnych powodów zakłócony, niepełny, niedokończony, może przebiegać patologicznie. Konsekwencją może być poczucie obcości własnej osoby, utrata poczucia jedności i integralności własnego ja, różnorodne zaburzenia w ramach relacji interpersonalnych (Grochmal-Bach, Pąchalska, 2004). Poczucie tożsamości ma istotny wpływ na integrację osobowości, która w okresie dojrzewania ciągle się rozwija. Jest ono czymś tak charakterystycznym i intymnym dla człowieka, że wszelkie pęknięcia w jego ramach mogą odbijać się w różnych sferach funkcjonowania jednostki, aż po głębokie i całościowe zaburzenia osobowości (Pilarska, Suchańska, 2015). Dlatego tak istotne jest ciągłe monitorowanie przebiegu kształtowania się tożsamości pośród współczesnych nastolatków.

\section{PROBLEM BADAŃ WŁASNYCH}

Badania nad poczuciem tożsamości mają w psychologii już długą tradycję i cały czas są podejmowane $\mathrm{w}$ różnych kontekstach. Zdecydowana większość $\mathrm{z}$ nich dotyczy jednak aspektów formalnych związanych z procesem kształtowania się poczucia tożsamości, takich jak statusy tożsamości (Bartoszuk, Pittman, 2010; Crocetti, Luyckx, Scrignaro, Sica, 2011; Meeus, van de Schoot, Keijsers, Schwartz, Branje, 2010) czy style tożsamości (Berzonsky, Cieciuch, Duriez, Soenens, 2011; Duriez, Luyckx, Soenens, Berzonsky, 2012; Seaton, Beaumont, 2014). Badania treści poczucia tożsamości w literaturze zagranicznej występują rzadko (Sica, 2009) i zwykle dotyczą bardzo specyficznych wymiarów poczucia tożsamości (Morgan, 2012). W literaturze polskiej właściwie zagadnienie to należy do wyjątków (Batory, Brygoła, Oleś, 2016). Nie znamy więc odpowiedzi na pytanie, co jest treścią poczucia tożsamości współczesnych polskich nastolatków. Niniejsze badanie, polegające na wywiadzie pisemnym, ma wypełnić tę istotną lukę. Przy tym ma ono nie tylko określić, co staje się treścią odpowiedzi na pytanie: kim jesteś? (charakterystyka treściowa), ale także pomóc w zrozumieniu sposobu, w jaki młodzi ludzie formułują odpowiedź na to pytanie (charakterystyka formalna). Sformułowano dwie hipotezy.

Hipoteza 1. Poczucie tożsamości młodzieży szkoły ponadgimnazjalnej (w okresie późnej adolescencji) jest bardziej rozbudowane niż poczucie tożsamości uczniów szkoły gimnazjalnej (w okresie wczesnej adolescencji).

Zakłada się, iż wypowiedzi uczniów szkoły ponadgimnazjalnej będą zawierały bardziej bogatą w treść i wyczerpującą odpowiedź na pytanie „kim jesteś?” niż wypowiedzi uczniów 
szkoły gimnazjalnej. Hipoteza ta znajduje swoje uzasadnienie w prawidłowościach rozwoju poznawczego, jak i rozwoju osobowości, które następują wraz z wiekiem. Hipoteza będzie weryfikowana za pomocą oceny wypowiedzi młodzieży przez sędziów kompetentnych.

Hipoteza 2. Poczucie tożsamości młodzieży ponadgimnazjalnej (w okresie późnej adolescencji) jest treściowo różne od poczucia tożsamości młodzieży gimnazjalnej (w okresie wczesnej adolescencji).

Zakłada się, iż młodzież szkół ponadgimnazjalnych częściej niż młodzież szkół gimnazjalnych będzie podkreślała swoją niezależność i odrębność od innych, częściej będzie także używać określeń oryginalnych. Jest to związane z procesem indywiduacji, który nasila się w okresie środkowej adolescencji (Blos, 1967; Ruszkowska, 1997). W okresie adolescencji stopniowo zwiększa się udział młodych w poczuciu ich podmiotowości i niezależności (Oleszkowicz, Senejko, 2013). Przewiduje się również, że młodzież szkół ponadgimnazjalnych częściej w opisie poczucia swojej tożsamości będzie używać charakterystyk dotyczących swojej osobowości. Byłoby to dowodem na zwracanie większej uwagi na ten aspekt osobistego rozwoju w porównaniu do rozwoju wyglądu fizycznego, który staje się częstym tematem rozważań zwłaszcza w pierwszej fazie adolescencji, czyli w okresie szkoły gimnazjalnej. To wtedy zaczynają się u nastolatków gwałtowne zmiany w wyglądzie fizycznym.

\section{METODA}

\section{OSOBY BADANE}

W pierwszym etapie badań brało udział 60 uczniów klas pierwszych i drugich liceum ogólnokształcącego w województwie mazowieckim, w tym 21 chłopców i 39 dziewcząt. W drugim etapie badań wzięło udział 188 uczniów, z czego 96 ze szkoły gimnazjalnej (w wieku od 13 do 16 lat) oraz 92 ze szkoły średniej (w wieku od 18 do 19 lat). Jeśli chodzi o podział ze względu na płeć, to wśród osób badanych znalazło się 72 chłopców i 116 dziewcząt (w tym w gimnazjum odpowiednio: 41 i 55, w szkole średniej: 31 i 61). Zarówno gimnazjum, jak i szkoła średnia (liceum ogólnokształcące), do których uczęszczały osoby badane, są częścią jednego zespołu szkół na Śląsku. Jest to placówka uważana za jedną z lepszych w województwie, co oznacza, że uczniowie do niej należący odznaczają się zazwyczaj wyższymi wynikami w nauce od swoich statystycznych rówieśników. Badania zakończyły się w okresie przed likwidacją szkól gimnazjalnych - te przestały w Polsce istnieć w 2019 roku.

\section{MATERIAŁY/ZASTOSOWANE NARZĘDZIA}

Do badania treści poczucia tożsamości posłużyła ankieta własnego autorstwa. Badanie treści zostało zainspirowane teorią rozwoju psychospołecznego Eriksona (1968). Ankietę tworzyło kilka pytań, które zostały sformułowane podczas dyskusji eksperckiej. Ankieta ostatecznie składała się ze wstępu, będącego instrukcją badania, oraz części właściwej, zawierającej cztery pytania otwarte („Kim jesteś?”, „Kim możesz być?”, „Czy stawiasz sobie jakieś pytania dotyczące samego/samej siebie? Jeśli tak, jakie są to pytania?”, „Na jakie inne, ważne dla Ciebie pytania szukasz teraz odpowiedzi?”). Odnosiły się one do aktualnego i projektowanego poczucia tożsamości oraz procesu eksploracyjnego. Dlatego narzędzie nazwano Badanie procesu eksploracyjnego. W niniejszym badaniu skupiono się tylko na analizie 
odpowiedzi na pytanie dotyczące aktualnego poczucia tożsamości, a więc pytania: kim jesteś?

\section{PROCEDURA BADANIA}

Pierwszym krokiem procedury badawczej było przeprowadzenie badań pilotażowych. Uczniowie klas pierwszych i drugich wypełniali ankietę przygotowaną przez autora badań. Składała się ona $z$ kilku pytań otwartych, mających na celu zbadanie różnych aspektów poczucia tożsamości. Młodzież została dokładnie zaznajomiona $\mathrm{z}$ instrukcją badania, a po jego zakończeniu została poproszona o komentarz do badania (m.in. w kwestii czytelności poleceń, wrażeń po badaniu). Na podstawie badania pilotażowego zostały dokonane niewielkie korekty językowe w ankiecie mającej służyć badaniom właściwym.

Kolejnym krokiem było przeprowadzenie badań na terenie zespołu szkół składającego się ze szkoły gimnazjalnej oraz liceum ogólnokształcącego. Badanie zostało przeprowadzone w trzech klasach gimnazjalnych i trzech licealnych. Było wykonywane w obecności autora badań. Ankietę z pytaniami uczniowie wypełniali pisemnie w czasie jednej lekcji. Badanie zostało poprzedzone komentarzem wstępnym, zachęcającym do uważnego przeczytania instrukcji i rzetelnego wypełnienia ankiety.

\section{ANALIZA JAKOŚCIOWA POCZUCIA TOŻSAMOŚCI}

Aby materiał pochodzący z badań jakościowych mógł zostać poddany analizie badawczej, należało dokonać procesu zamiany materiału badawczego na wskaźniki. Na początku materiał badawczy został sczytany przez dwóch niezależnych badaczy, po czym zostały z niego wyodrębnione kategorie treściowe oraz formalne, jakie można było w materiale zauważyć. Kategorie zostały opisane i został określony ich zakres treściowy, co przedstawiono w tabelach 1 i 2.

Tabela 1. Kategorie treściowe

\begin{tabular}{|c|c|c|}
\hline Nazwa kategorii & Opis kategorii & Przykład wypowiedzi \\
\hline nieokreśloność & $\begin{array}{l}\text { badany ma problemy z określeniem swojej } \\
\text { tożsamości, nie zna odpowiedzi na pytanie, kim } \\
\text { jest, bądź jego odpowiedź jest bardzo zdawkowa } \\
\text { lub też pisze o swoich problemach w określeniu, } \\
\text { kim jest }\end{array}$ & $\begin{array}{l}\text { „jestem człowiekiem”, } \\
\text { „trudno mi odpowiedzieć na to pytanie” }\end{array}$ \\
\hline przynależność & $\begin{array}{l}\text { badany określa to, kim jest, w odniesieniu do } \\
\text { jakiejś grupy albo społeczności, w której się } \\
\text { znajduje }\end{array}$ & $\begin{array}{l}\text { „jestem uczniem", }, \text { jestem dzieckiem swoich } \\
\text { rodziców" }\end{array}$ \\
\hline niezależność & $\begin{array}{l}\text { badany podkreśla swoją niezależność, odrębność } \\
\text { od innych }\end{array}$ & „mam zawsze swój sposób myślenia” \\
\hline osobowość & $\begin{array}{l}\text { badany określa swoją tożsamość, podając swoje } \\
\text { cechy charakteru i/lub osobowości }\end{array}$ & $\begin{array}{l}\text { "jestem optymistą", }, \text { jestem dążącą do celu, } \\
\text { pewną siebie nastolatką" }\end{array}$ \\
\hline oryginalność & $\begin{array}{l}\text { badany określa siebie w słowach, pojęciach } \\
\text { bardzo oryginalnych, rzadko spotykanych, nieco } \\
\text { dziwnych lub nawet szokujących }\end{array}$ & $\begin{array}{l}\text { „Jjestem kroplą w morzu miotanym wieloma } \\
\text { falami”, ,jestem niebytem wyłaniającym się ze } \\
\text { wszechświata" }\end{array}$ \\
\hline elementy pozytywne & $\begin{array}{l}\text { osoba badana określa siebie słowami wskazują- } \\
\text { cymi na pozytywny odbiór własnej osoby }\end{array}$ & $\begin{array}{l}\text { „jestem osobą szczęśliwą i spełnioną", ,'jestem po- } \\
\text { zytywnym nastolatkiem z wieloma marzeniami” }\end{array}$ \\
\hline elementy negatywne & $\begin{array}{l}\text { osoba badana określa siebie słowami wskazują- } \\
\text { cymi na negatywny odbiór własnej osoby }\end{array}$ & $\begin{array}{l}\text { „1]estem ponurym pesymistą, }{ }^{\prime \prime}, \text { jestem nieudacz- } \\
\text { nikiem" }\end{array}$ \\
\hline
\end{tabular}




\begin{tabular}{|c|c|c|}
\hline Nazwa kategorii & Opis kategorii & Przykład wypowiedzi \\
\hline zainteresowania & $\begin{array}{l}\text { badany w określeniu swojej tożsamości pisze } \\
\text { o swoich zainteresowaniach, hobby, sposobie } \\
\text { spędzania wolnego czasu itd. }\end{array}$ & „jestem zapalonym fanem koszykówki” \\
\hline poglądy & $\begin{array}{l}\text { badany w określeniu swojej tożsamości używa } \\
\text { odniesień do światopoglądu, filozofii, religii, } \\
\text { przynależności ideowej }\end{array}$ & „jestem osobą głęboko wierzącą" \\
\hline tylko ja & $\begin{array}{l}\text { badany w określeniu swojej tożsamości pisze } \\
\text { tylko o sobie }\end{array}$ & $\begin{array}{l}\text { „jestem chłopakiem, dobrym uczniem, lubię } \\
\text { sklejać modele, kocham sport, cały czas chcę się } \\
\text { doskonalić w swoich zainteresowaniach" }\end{array}$ \\
\hline ja i inni & $\begin{array}{l}\text { badany w określeniu swojej tożsamości używa } \\
\text { odniesień do innych osób, np. bliskich, przyjaciół, } \\
\text { kolegów }\end{array}$ & $\begin{array}{l}\text { "mam grono swoich znajomych, z którymi lubię } \\
\text { spędzać wolny czas" }\end{array}$ \\
\hline przeciwstawność & $\begin{array}{l}\text { badany określa siebie w kategoriach opozycyj- } \\
\text { nych, zwraca uwagę na ambiwalentność swojej } \\
\text { tożsamości }\end{array}$ & $\begin{array}{l}\text { "jestem dobry i zły",,",zasami jestem pilnym } \\
\text { uczniem, a czasami leniwym dzieckiem" }\end{array}$ \\
\hline porównawczość & $\begin{array}{l}\text { badany określa swoją tożsamość w porównaniu } \\
\text { do innej osoby/innych osób }\end{array}$ & „jestem większą pesymistką niż moje koleżanki” \\
\hline rodzina & $\begin{array}{l}\text { badany wspomina w swojej wypowiedzi aspekty } \\
\text { rodzinne }\end{array}$ & $\begin{array}{l}\text { "jestem członkiem 6-osobowej rodziny",,,mam } \\
2 \text { braci i } 2 \text { siostry" }\end{array}$ \\
\hline szkoła & $\begin{array}{l}\text { badany wspomina szkołę lub aspekty edukacyjne } \\
\text { w swojej wypowiedzi }\end{array}$ & „jestem uczniem”, ,Ilubię matematykę i fizykę" \\
\hline rówieśnicy & $\begin{array}{l}\text { badany wspomina swoich kolegów, przyjaciółze } \\
\text { szkoły lub spoza szkoły }\end{array}$ & „"mam kilkoro dobrych przyjaciół” \\
\hline stałość & $\begin{array}{l}\text { badany opisuje swoją tożsamość jako trwały stan, } \\
\text { używa czasownika „jestem...., nie ma tutaj mowy } \\
\text { o niestabilności czy niepewności tego, kim się jest }\end{array}$ & $\begin{array}{l}\text { „jestem uczennicą, córką swoich rodziców, lubię } \\
\text { tenis i często chodzę z przyjaciółmi na imprezy” }\end{array}$ \\
\hline zmienność & $\begin{array}{l}\text { badany podkreśla niestabilność i zmienność } \\
\text { swojego poczucia tożsamości; zamiast pisać, kim } \\
\text { jest, opisuje np., kim bywa albo kim chciałby być }\end{array}$ & $\begin{array}{l}\text { "to, kim jestem, ciągle się zmienia, raz jestem } \\
\text { wesołym nastolatkiem, a raz przygnębionym } \\
\text { obywatelem kraju” }\end{array}$ \\
\hline dynamika & $\begin{array}{l}\text { w opisie widoczne są wątki mówiące o kreowaniu } \\
\text { tożsamości, o jej tworzeniu, o wpływie na jej } \\
\text { konstruowanie }\end{array}$ & $\begin{array}{l}\text { "ciągle tworzę siebie, zastanawiam się, kim mam } \\
\text { być, i próbuję siebie w różnych rolach" }\end{array}$ \\
\hline
\end{tabular}

Tabela 2. Kategorie formalne

\begin{tabular}{|c|c|c|}
\hline Nazwa kategorii & Opis kategorii & Przykład wypowiedzi \\
\hline spójność & $\begin{array}{l}\text { badany określa swoją tożsamość jako zamkniętą } \\
\text { całość, wszystkie jej elementy pasują do siebie }\end{array}$ & $\begin{array}{l}\text { "jestem młodym, pełnym pomysłów, rozrywko- } \\
\text { wym chłopakiem" }\end{array}$ \\
\hline „wyliczanka” & $\begin{array}{l}\text { osoba określa siebie w różnych kategoriach, nie- } \\
\text { stanowiących jednak zamkniętej całości, często } \\
\text { oddzielonych przecinkiem }\end{array}$ & „jestem uczniem, kobietą, skautem, dzieckiem” \\
\hline wypowiedź rozbudowana & $\begin{array}{l}\text { osoba daje bogatą, wyczerpującą odpowiedź } \\
\text { (wykraczającą poza } 2 \text { zdania lub składającą się } \\
\text { z 1-2 zdań, ale bardzo rozbudowanych) }\end{array}$ & $\begin{array}{l}\text { „jestem młodą dziewczyną, szukającą swojego } \\
\text { miejsca we wszechświecie, obecnie uczennica, ale } \\
\text { także harcerką; mam grono przyjaciół, z którymi } \\
\text { lubię spędzać wolny czas, pasjonuję się modą, cza- } \\
\text { sami bywam uparta, ale zazwyczaj jestem skłonna } \\
\text { do współpracy, jestem także lokalną patriotką...” }\end{array}$ \\
\hline wypowiedź prosta & $\begin{array}{l}\text { osoba daje wypowiedź krótką, lakoniczną, ubogą } \\
\text { w treść (ograniczającą się do 1-2 krótkich zdań) }\end{array}$ & $\begin{array}{l}\text { „jestem uczniem, skromnym chłopakiem, niewy- } \\
\text { różniającym się od moich rówieśników" }\end{array}$ \\
\hline wypowiedź aktywna & $\begin{array}{l}\text { badany określa siebie, odnosząc się do jakiejś } \\
\text { działalności fizycznej lub umysłowej, używa } \\
\text { czasowników }\end{array}$ & „dużo ćwiczę, ciągle o czymś myślę" \\
\hline wypowiedź statyczna & $\begin{array}{l}\text { badany określa siebie w kategoriach statycznych, } \\
\text { używa rzeczowników }\end{array}$ & „jestem uczniem, harcerzem, miłym chłopakiem” \\
\hline
\end{tabular}


Troje sędziów kompetentnych, korzystając ze spisu i opisu poszczególnych kategorii, czytało wypowiedzi uczniów, oceniając, czy poszczególne kategorie się w nich pojawily (nadając wartość 1) lub też nie pojawiły (nadając wartość 0 ). W ten sposób otrzymano skalę 2-stopniową: 0 lub 1, gdzie 0 oznaczało brak wystąpienia danej kategorii treściowej lub formalnej w wypowiedzi, a 1 - wystąpienie w wypowiedzi danej kategorii treściowej lub formalnej. Uzyskane konkretne wskaźniki mogły następnie zostać poddane analizie statystycznej.

\section{CZĘSTOŚCI WYSTĘPOWANIA POSZCZEGÓLNYCH KATEGORII}

W celu zaprezentowania wstępnej analizy wypowiedzi uczniów szkół gimnazjalnej i licealnej posłużono się opisem statystycznym $\mathrm{w}$ postaci przedstawienia procentowej częstości występowania poszczególnych kategorii treściowych i formalnych w odpowiedziach uzyskanych na pytanie: „kim jestem?”. W tabelach 3 i 4 zaprezentowano wyniki częstotliwości kategorii treściowych i formalnych od występujących najczęściej do występujących najrzadziej w wypowiedziach młodzieży szkół gimnazjalnej i licealnej łącznie (kolumna 2) oraz z podziałem na uczniów szkół gimnazjalnej i licealnej (kolumny 3 i 4).

Tabela 3. Występowanie poszczególnych kategorii treściowych w wypowiedziach młodzieży szkół gimnazjalnej i licealnej

\begin{tabular}{lccc}
\hline \multicolumn{1}{c}{ Nazwa kategorii } & Szkoły łącznie (\%) & Szkoła gimnazjalna (\%) & Szkoła licealna (\%) \\
\hline stałość & 90,4 & 90,4 & 89,1 \\
\hline osobowość & 63,8 & 58,3 & 69,6 \\
\hline szkoła & 63,8 & 67,7 & 59,8 \\
\hline przynależność & 61,2 & 61,5 & 60,9 \\
\hline tylko ja & 57,4 & 52,2 & 57,4 \\
\hline elementy pozytywne & 50,0 & 47,9 & 52,2 \\
\hline ja i inni & 41,5 & 37,5 & 45,7 \\
\hline zainteresowania & 30,9 & 34,4 & 27,2 \\
\hline rówieśnicy & 23,9 & 24,0 & 23,9 \\
\hline elementy negatywne & 22,9 & 18,8 & 27,2 \\
\hline rodzina & 22,3 & 16,7 & 28,3 \\
\hline niezależność & 19,1 & 20,8 & 17,4 \\
\hline przeciwstawność & 17,0 & 12,5 & 21,7 \\
\hline nieokreśloność & 13,8 & 13,5 & 14,1 \\
\hline oryginalność & 12,8 & 7,3 & 18,5 \\
\hline zmienność & 11,7 & 10,4 & 13,0 \\
\hline dynamika & 11,7 & 12,5 & 10,9 \\
\hline porównawczość & 8,0 & 9,4 & 6,5 \\
\hline poglądy & 7,4 & 3,1 & 12,0 \\
\hline
\end{tabular}

Badani w zdecydowanej większości $(86,2 \%)$ udzielali odpowiedzi na pytanie, kim są. Tylko w 13,8\% przypadków młodzi ludzie mieli problemy z określeniem swojej tożsamości (kategoria nieokreśloność). Badana młodzież charakteryzowała się dość stabilnym poczuciem własnej tożsamości, tzn. odpowiadając na pytanie o to, kim jest, odpowiadała wprost na zadane pytanie, nadając mu określoną treść (kategoria statość). Kategorie treściowe, które pojawiały się w odpowiedziach młodzieży najczęściej, to: osobowość, szkota i przynależność. Uczniowie szkoły licealnej, formułując wypowiedź na temat poczucia własnej tożsamości, 
podawali najczęściej swoje cechy charakteru lub osobowości (kategoria osobowość). Uczniowie szkoły gimnazjalnej wspominali szkołę lub aspekty edukacyjne (kategoria szkota). Często zarówno gimnazjalni, jak i licealni adolescenci określali to, kim są, w odniesieniu do jakiejś grupy lub społeczności, do której należą (kategoria przynależność).

Warte odnotowania jest częstsze występowanie elementów pozytywnych w porównaniu do elementów negatywnych zawartych w odpowiedziach młodzieży. Można też zaznaczyć, iż 17\% badanych osób używało w odpowiedzi na zadane pytanie kategorii opozycyjnych, zwracając tym samym uwagę na ambiwalentność poczucia swojej tożsamości (kategoria przeciwstawność). Odsetek ten był wyraźnie wyższy u licealistów.

Kategoriami treściowymi, które najrzadziej pojawiały się w wypowiedziach młodzieży, były: zmiennośc, dynamika, porównawczośc i poglądy. Klasyfikacja ta wygląda nieco inaczej w przypadku poszczególnych typów szkól. Do światopoglądu, filozofii, religii czy jakiejkolwiek przynależności ideowej (kategoria poglądy) odnosiła się niewielka liczba gimnazjalistów. Uczniowie szkoły gimnazjalnej stosunkowo rzadko określali się też w słowach i pojęciach bardzo oryginalnych oraz rzadko spotykanych (kategoria oryginalność). Z kolei uczniowie szkoły licealnej najrzadziej określali swoją tożsamość w porównaniu do innej osoby bądź innych osób (kategoria porównawczość).

Tabela 4. Występowanie poszczególnych kategorii formalnych w wypowiedziach młodzieży szkół gimnazjalnej i licealnej

\begin{tabular}{lccc}
\hline \multicolumn{1}{c}{ Nazwa kategorii } & Szkoły łącznie (\%) & Szkoła gimnazjalna (\%) & Szkoła licealna (\%) \\
\hline spójnośc & 75,0 & 82,3 & 67,4 \\
\hline wypowiedź rozbudowana & 61,7 & 62,5 & 60,9 \\
\hline wypowiedź aktywna & 60,6 & 60,4 & 60,9 \\
\hline wypowiedź prosta & 38,3 & 38,5 & 38,0 \\
\hline wypowiedź statyczna & 38,3 & 39,6 & 37,0 \\
\hline wyliczanka & 20,0 & 15,6 & 23,9 \\
\hline
\end{tabular}

Zdecydowana większość uczniów konstruowała wypowiedź na temat swojej tożsamości jako zamkniętej całości, złożonej z elementów pasujących do siebie. Kategoria spójność występowała wprawdzie częściej wśród gimnazjalistów, ale wśród licealistów była także dominującą kategorią formalną. Większość odpowiedzi uzyskanych w wyniku badania stanowiły wypowiedzi rozbudowane, dające stosunkowo bogatą i wyczerpującą odpowiedź na zadane pytanie (kategoria wypowiedź rozbudowana). Tylko jedna piąta ankietowanej młodzieży formułowała odpowiedź jako swego rodzaju wyliczankę różnych kategorii, niestanowiących jednak zamkniętej całości (kategoria wyliczanka).

\section{ZRÓŻNICOWANIE UCZNIÓW GIMNAZJUM I LICEUM W ZAKRESIE WYPOWIEDZI NA TEMAT POCZUCIA TOŻSAMOŚCI}

W celu zweryfikowania hipotezy na temat różnic między treściowymi i formalnymi wypowiedziami uczniów szkół gimnazjalnych i licealnych zastosowano analizę za pomocą tabeli krzyżowych oraz tradycyjny test nieparametryczny chi-kwadrat. Zmiennymi testowanymi były $\mathrm{z}$ jednej strony szkoła (gimnazjalna lub licealna), z drugiej strony - wystąpienie bądź niewystąpienie danej kategorii treściowej lub formalnej w wypowiedziach uczniów. Za istotne przyjęto różnice na poziomie $p<0,05$, wyniki na poziomie $p \geq 0,05 \mathrm{i} p \leq 0,1$ uznano natomiast za tendencję statystyczną. Wyniki zostały zebrane w tabeli 5 . 
Tabela 5. Wartość statystyki chi-kwadrat Pearsona w odniesieniu do częstości występowania danych kategorii w wypowiedziach uczniów szkół gimnazjalnej i licealnej

\begin{tabular}{|c|c|c|}
\hline & $\begin{array}{c}\text { Wartość statystyki } \\
X^{2} \text { Pearsona }\end{array}$ & Istotność dwustronna \\
\hline \multicolumn{3}{|l|}{ Kategorie treściowe } \\
\hline 1. nieokreśloność & 0,01 & 0,91 \\
\hline 2. przynależność & 0,01 & 0,93 \\
\hline 3. niezależność & 0,36 & 0,55 \\
\hline 4. osobowość & 2,57 & $0,10^{*}$ \\
\hline 5. oryginalność & 5,28 & $0,02^{* *}$ \\
\hline 6. elementy pozytywne & 0,34 & 0,56 \\
\hline 7. elementy negatywne & 1,89 & 0,17 \\
\hline 8. zainteresowania & 1,14 & 0,29 \\
\hline 9. poglądy & 5,32 & $0,02^{* *}$ \\
\hline 10. tylko ja & 2,05 & 0,15 \\
\hline 11. ja i inni & 1,27 & 0,26 \\
\hline 12. przeciwstawność & 2,84 & $0,09^{*}$ \\
\hline 13. porównawczość & 0,52 & 0,47 \\
\hline 14. rodzina & 3,64 & $0,06^{*}$ \\
\hline 15. szkoła & 1,28 & 0,26 \\
\hline 16. rówieśnicy & 0,00 & 0,99 \\
\hline 17. stałość & 0,35 & 0,56 \\
\hline 18. zmienność & 0,31 & 0,58 \\
\hline 19. dynamika & 0,12 & 0,73 \\
\hline \multicolumn{3}{|l|}{ Kategorie formalne } \\
\hline 20. spójność & 5,56 & $0,02^{* *}$ \\
\hline 21. wyliczanka & 2,04 & 0,15 \\
\hline 22. wypowiedź rozbudowana & 0,05 & 0,82 \\
\hline 23. wypowiedź prosta & 0,01 & 0,94 \\
\hline 24. wypowiedź aktywna & 0,00 & 0,95 \\
\hline 25. wypowiedź statyczna & 0,14 & 0,71 \\
\hline
\end{tabular}

** istotność statystyczna; * tendencja statystyczna

Biorąc pod uwagę treść wypowiedzi młodzieży, istotna statystycznie okazała się różnica w stosowaniu przez młodych ludzi bardzo oryginalnych i rzadko spotykanych określeń służących do opisu tożsamości (kategoria oryginalność). Częściej takich słów używali badani z klas licealnych. Różnicę między licealistami a gimnazjalistami można zauważyć, biorąc pod uwage odniesienia do światopoglądu, filozofii, religii czy przynależności ideowej (kategoria poglady). Uczniowie szkoły licealnej istotnie częściej stosowali tę kategorię w wypowiedzi dotyczącej poczucia swojej tożsamości. Na podstawie przeprowadzonych analiz można wskazać tendencję statystyczną sugerującą, iż uczniów szkół gimnazjalnej i licealnej odróżnia określanie swojej tożsamości w terminach dotyczących ich cech charakteru i osobowości (kategoria osobowość). Z analizy wynika, iż to uczniowie szkoły licealnej częściej stosują opis swoich cech charakteru i osobowości. Tendencja statystyczna została ujawniona także w przypadku kategorii rodzina. $Z$ analizy wynika, iż to uczniowie szkoły licealnej stosunkowo częściej, w porównaniu do uczniów szkoły gimnazjalnej, poruszali w swoich wypowiedziach aspekty rodzinne. Wyraźnej różnicy między gimnazjalistami a licealistami nie odnotowano w zakresie określania siebie w kategoriach opozycyjnych, ukazujących 
swoistą ambiwalentność poczucia tożsamości (kategoria przeciwstawność). Można jednak zaznaczyć, że istotność znalazła się w tym wypadku w granicach wykazania tendencji statystycznej wskazującej na to, iż to licealiści częściej używali określeń ambiwalentnych.

Kategorie formalne nie różnicowały w istotny sposób odpowiedzi uczniów szkół gimnazjalnej i licealnej. Jedyna różnica została ujawniona w odniesieniu do formy wypowiedzi, jaką była spójność (kategoria spójność). Uczniowie szkoły gimnazjalnej częściej od uczniów szkoły licealnej określali swoją tożsamość jako zamkniętą całość, której poszczególne elementy pasują do siebie.

\section{DYSKUSJA WYNIKÓW}

Wstępna analiza danych jakościowych ukazała, w jakich obszarach treściowych poruszają się adolescenci odpowiadający na pytanie: kim jestem? Prób wyodrębniania sfer, w których dokonuje się poszukiwanie poczucia własnej tożsamości, dokonali już Erikson (1997) i Marcia (1966, 1980), ale poszczególne płaszczyzny eksploracji tożsamościowej należy nieustannie poddawać weryfikacji. Brakuje w literaturze obszerniejszych opisów obszarów tożsamościowych. Znajdziemy w tej materii tylko wyjątki (Kłym-Guba, Cieciuch, 2016). Przeprowadzone badania pozwoliły na wyodrębnienie domen na podstawie tekstu tożsamościowego uzyskanego bezpośrednio od nastolatków. W ten sposób uzyskano aż 19 kategorii treściowych i sześć kategorii formalnych, jakich używali młodzi ludzie do odpowiedzi na pytanie: kim jesteś? Zastosowane tutaj podejście badawcze daje większe możliwości eksploracyjne i pozwala na uchwycenie niuansów związanych $z$ indywidualną dynamiką kształtowania poczucia tożsamości.

Dzięki wstępnej analizie danych jakościowych można zauważyć, iż zdecydowana większość badanej młodzieży cechuje się stałością poczucia tożsamości. Elementy pozytywne przeważają nad elementami negatywnymi, choć pojawienie się tych ostatnich u prawie jednej czwartej osób badanych powinno zwracać uwagę, zważywszy fakt, jak ważna jest w tym okresie rozwojowym samoocena (Pilarska, Suchańska, 2015). Kategorią, która występowała częściej niż rodzina czy rówieśnicy, była szkoła. Ten wynik może nieco zaskakiwać, gdyż w świetle wielu teorii w okresie dorastania szczególną rolę zajmują rówieśnicy, którzy przejmują pierwszeństwo nawet przed rodziną - to oni dają często możliwość przetestowania projektu tożsamościowego (Forthun, Montgomery, Bell, 2006). Taki wynik może jednak mieć związek z miejscem i czasem przeprowadzenia badania oraz specyfiką badanej grupy uczniów uczęszczających do jednej z lepszych szkół w województwie, a więc skupionych na aspektach edukacyjnych prawdopodobnie bardziej od swoich rówieśników. Większa część badanej młodzieży podkreślała swoją przynależność do jakiejś grupy, co stanowiło dowód na istotny wymiar, którym jest tożsamość społeczna. Ten wymiar tożsamości podkreślany jest także przez wielu współczesnych badaczy (Jenkins, 2014; Oleś, 2012). Jedna trzecia nastolatków pisała o swoich zainteresowaniach, tylko kilka procent respondentów w opisie swojej tożsamości użyło natomiast odniesień do światopoglądu. Ten fakt każe zweryfikować tradycyjne poglądy Eriksona (1997) i Marcii (1980), którzy uważali płaszczyznę światopoglądową za jedną z najistotniejszych w kształtowaniu poczucia tożsamości. Wypowiedzi aktywne i rozbudowane przeważały nad wypowiedziami statycznymi i prostymi. Niemniej jednak około $14 \%$ młodych ludzi miało duży kłopot $\mathrm{z}$ odpowiedzią na pytanie, kim są. Ten odsetek jest nieco większy od uzyskanego przez Brzezińską i Piotrowskiego (2009) w badaniach nad statusami tożsamości. Zarówno wyniki opublikowane przez wspomnianych autorów, jak i obecne badania pokazują, że w każdej grupie adolescentów znajdują się osoby mające poważne problemy z poczuciem własnej tożsamości, w związku z czym istotne wydaje się pomaganie młodym ludziom w szukaniu odpowiedzi na jedno $\mathrm{z}$ najważniejszych pytań tego okresu życia. 
Nie wszystkie otrzymane wyniki odzwierciedliły przyjęte wcześniej założenia o różnicach treściowych między uczniami szkoły gimnazjalnej a uczniami szkoły średniej. W opisie poczucia tożsamości uczniowie szkoły licealnej odwoływali się do swoich cech charakteru i osobowości częściej niż uczniowie szkoły gimnazjalnej, co zostało ujęte w hipotezach badawczych. Istotnie częściej stosowali też pojęcia oryginalne, co także zostało założone wcześniej. Nie uzyskano natomiast wyników mogących potwierdzić fakt, iż uczniowie szkoły średniej częściej podkreślają swoją niezależność i odrębność od innych. Odnotowano, iż uczniowie szkoły licealnej częściej niż uczniowie gimnazjum odwoływali się w swoich wypowiedziach do poglądów. Jest to zgodne z prawidłowościami rozwoju młodzieży i faktem, że w późnej adolescencji następują już pierwsze próby integracji światopoglądu. Stosunkowo ciekawym odkryciem było to, iż wypowiedzi uczniów gimnazjum były bardziej spójne, podczas gdy wypowiedzi uczniów szkoły licealnej nie okazały się bardziej rozbudowane, aktywne czy dynamiczne. W świetle badań nad wydłużającym się okresem wchodzenia w dorosłość taki wynik może przemawiać za stwierdzeniem, iż to na okres późnej adolescencji przypada obecnie największy kryzys tożsamościowy i swego rodzaju dezintegracja tożsamościowa. Zdają się to potwierdzać także wyniki innych badań (Brzezińska, Piotrowski, 2009). Potwierdzenie takiej hipotezy wymaga jednak ciągle nowych analiz.

Zaprezentowane badania, stanowiąc wkład w lepsze poznanie procesu formowania się poczucia tożsamości współczesnych nastolatków, wymagają wciąż dalszych analiz. Szczególnie wartościowe mogłoby być przeprowadzenie bardziej pogłębionych wywiadów, pozwalających uchwycić nie tylko treść i formę poczucia tożsamości dorastającej młodzieży, lecz także dynamikę stojącą za taką, a nie inną treścią tego poczucia. Pomocne w lepszym zrozumieniu procesu kształtowania się tożsamości adolescentów byłoby zestawienie badań jakościowych i ilościowych w tym względzie, a także analiza związków między wybranymi aspektami poczucia tożsamości a innymi wymiarami psychologicznymi kreującymi się w okresie dorastania, takimi jak obraz siebie czy poczucie własnej wartości. 


\section{BIBLIOGRAFIA}

Bardziejewska, M. (2013). Okres dorastania. Jak rozpoznać potencjał nastolatków? W: A. I. Brzezińnka (red.), Psychologiczne portrety człowieka. Praktyczna psychologia rozwojowa (s. 345-377). Sopot: GWP.

Bartoszuk, K., Pittman, J. (2010). Does family structure matter? A domain specific examination of identity exploration and commitment. Youth \& Society, 42, 155-173. https://doi.org/10.1177/0044118X10377648

Batory, A., Brygoła, E., Oleś, P. (2016). Odsłony tożsamości. Warszawa: PWN.

Berzonsky, M. D., Cieciuch, J., Duriez, B., Soenens, B. (2011). The how and what of identity formation: associations between identity styles and value orientations. Personality and Individual Differences, 50, 295-299. https://doi.org/10.1016/j.paid.2010.10.007

Blos, P. (1967). The second individuation process of adolescence. Psychoanalytic Study of the Child, 22, 162-186. https://doi.org/10.1080/00797 308.1967.11822595

Brzezińska, A. I., Appelt, K., Ziółkowska, B. (2010). Psychologia rozwoju człowieka. W: J. Strelau, D. Doliński (red.), Psychologia akademicka. Podręcznik (t. 2, s. 95-294). Sopot: GWP.

Brzezińska, A., Piotrowski, K. (2009). Diagnoza statusów tożsamości w okresie adolescencji, wyłaniającej się dorosłości i wczesnej dorosłości za pomocą Skali Wymiarów Rozwoju Tożsamości (DIDS). Studia Psychologiczne, 47(3), 93-109.

Crocetti, E., Luyckx, K., Scrignaro, M., Sica, L. S. (2011). Identity formation in Italian emerging adults: a cluster-analytic approach and associations with psychosocial functioning. European Journal of Developmental Psychology, 8, 558-572. https://doi.org/10.1080/17405629.2011.576858

Czerwińska-Jasiewicz, M. (2015). Psychologia rozwoju młodzieży w kontekście biegu ludzkiego życia. Warszawa: Difin.

Duriez, B., Luyckx, K., Soenens, B., Berzonsky, M. (2012). A process-content approach to adolescent identity formation: examining longitudinal associations between identity styles and goal pursuits. Journal of Personality, 80, 135-161. https://doi.org/10.1111/j.1467-6494.2011.00729.x

Erikson, E. H. (1968). Identity. Youth and crisis. Nowy Jork: Norton.

Erikson, E. H. (1974). Dimensions of a new identity. Nowy Jork: Norton.

Erikson, E. H. (1997). Dzieciństwo i społeczeństwo. Poznań: Rebis.

Erikson, E. H. (2004). Tożsamość a cykl życia. Poznań: Zysk i S-ka.

Erikson, E. H. (2012). Dopełniony cykl życia. Gliwice: Helion.

Filipiak, E., Wiśniewska, M. (2014). Opieka i wychowanie. Późna faza dorastania. Warszawa: Instytut Badań Edukacyjnych.

Forthun, L. F., Montgomery, M., Bell, N. J. (2006). Identity formation in a relational context: a person-centered analysis of troubled youth. Identity, 6, 141-167. https://doi.org/10.1207/s1532706xid0602_2

Grochmal-Bach, B., Pąchalska, M. (2004). Tożsamośćczłowieka a teoria mikrogenetyczna. Kraków: WAM.

Havighurst, R. J. (1981). Developmental tasks and education. Nowy Jork: Longman.

Jaczewski, A. (red.). (2001). Biologiczne i medyczne podstawy rozwoju i wychowania. Warszawa: Żak.

Jenkins, R. (2014). Social identity. Londyn: Routledge.

Kłym-Guba, M., Cieciuch, J. (2016). Dynamika poszukiwania tożsamościowego w różnych domenach we wczesnej adolescencji: wyniki badań podłużnych. Roczniki Psychologiczne, 2, 221-237. http://dx.doi.org/10.18290/rpsych.2016.19.2-2pl

Kubacka-Jasiecka, D., Kuleta, M. (red.). (2008). W kręgu psychologicznej problematyki tożsamości. Kraków: Wydawnictwo Uniwersytetu Jagiellońskiego.

Lipska, A., Zagórska, W. (2011).,„Stająca się dorosłość” w ujęciu Jeffreya J. Arnetta jako rozbudowana faza liminalna rytuału przejścia. Psychologia Rozwojowa, 1, 9-21. https://doi.org/10.4467/20843879PR.11.001.0174

Marat, E. (2001). Depresja, poziom lęku i poczucia kontroli w aspekcie kształtowania się statusów tożsamości osobowej (w sferze - kontakty z rówieśnikami) u młodzieży szkół średnich i studentów. Psychologia Rozwojowa, 6(3-4), 333-343. http://dx.doi.org/10.4467/20843879 PR.13.006.1018

Marcia, J. E. (1966). Development and validation of ego-identity status. Journal of Personality and Social Psychology, 3, 551-558. https://doi. org/10.1037/h0023281

Marcia, J. E. (1980). Identity in adolescence. W: J. Adelson (red.), Handbook of adolescent psychology (s. 159-187). Nowy Jork: Wiley.

Meeus, W., van de Schoot, R., Keijsers, L. Schwartz, S. J, Branje, S. (2010). On the progression and stability of adolescent identity formation: a five -wave longitudinal study in early-to-middle and middle-to-late adolescence. Child Development, 81, 1565-1581. https://doi.org/10.1111/j. 1467-8624.2010.01492.x

Morgan, E. M. (2012). Not always a straight path: college students' narratives of heterosexual identity development. Sex Roles: A Journal of Research, 66, 79-93. https://doi.org/10.1007/s11199-011-0068-4

Musiał, D. (2007). Kształtowanie się tożsamości w adolescencji. W: P. Francuz, W. Otrębski (red.), Studia z psychologii w KUL. Tom 14. (s. 73-92). Lublin: Wyd. KUL.

Obuchowska, I. (2000). Adolescencja. W: B. Harwas-Napierała, J. Trempała (red.), Psychologia rozwoju człowieka. Charakterystyka okresów życia człowieka (s. 163-201). Warszawa: PWN.

Oleszkowicz, A., Senejko, A. (2013). Psychologia dorastania: zmiany rozwojowe w dobie globalizacji. Warszawa: PWN. 
Oleś, P. (2012). Tożsamość osobista i społeczna - płynna czy określona? W: W. Łukaszewski, D. Doliński, A. Fila-Jankowska, T. Maruszewski, A. Niedźwieńska, P. Oleś, T. Szkudlarek, Tożsamość. Trudne pytanie: kim jestem (s. 115-126). Sopot: Smak Słowa.

Opoczyńska, M. (1999). Moratorium psychospołeczne - szansa czy zagrożenie. W: A. Gałdowa (red.), Klasyczne i współczesne koncepcje osobowości (s. 123-141). Kraków: Wydawnictwo Uniwersytetu Jagiellońskiego.

Pilarska, A. (2016). Wokół pojęcia poczucia tożsamości: przegląd problemów i propozycja konceptualizacji. Nauka, 2, 123-141.

Pilarska, A., Suchańska, A. (2015). Poczucie tożsamości a przejawy zaburzeń osobowości: wyniki badań populacji nieklinicznej. Psychiatria Polska, 49, 599-613. http://dx.doi.org/10.12740/PP/21369

Ruszkowska, E. (1997). Okres adolescencji w ujęciu psychoanalitycznym. Dialogi - Zeszyty Instytutu Psychoanalizy i Psychoterapii, 1/2, 31-36.

Rydz, S. (2005). Osobowościowe uwarunkowania przekształceń statusów tożsamości osobowej u młodzieży (Niepublikowana praca doktorska). Uniwersytet Łódzki, Łódź.

Schaffer, D. R., Kipp, K. (2015). Psychologia rozwoju. Od dziecka do dorosłości. Gdańsk: Harmonia.

Seaton, C. L., Beaumont, S. (2014). Exploring the links between identity styles and forgiveness in university students. Canadian Journal of Behavioural Science, 46, 366-374. https://doi.org/10.1037/a0032009

Sica, L. S. (2009). Adolescents in different contexts: the exploration of identity through possible selves. Cognition, Brain, Behavior: An Interdisciplinary Journal, 13, 221-252.

Tillmann, K. J. (1996). Teorie socjalizacji. Społeczność, instytucja, upodmiotowienie. Warszawa: PWN. 